\title{
INTERNET USAGE BY THE ELDERLY IN SERBIA
}

\author{
UDC 316.773-0.53.9:004.738.5
}

\author{
Gordana Stojić \\ University of Niš, Faculty of Philosophy, Department of Sociology, Niš, Serbia
}

\begin{abstract}
In the last decades, the problems of the elderly have attracted the attention of the scientific and wider public, thus imposing themselves as issues of public policies. The growth of interest in the elderly is conditioned by: the increasing share of the elderly in the overall population, the change of their social status as well as the development of new conceptual frames (social exclusion, marginalization, ageism). Today the elderly live in a society which is characterized by the expansion of information-communication technologies (ICT). The Internet is a means of more efficient and faster completion of various activities, satisfaction of different needs and access to social resources. On the other hand, the adoption of new technologies has taken on a different pace when it comes to the generation affiliation. That is why it is important to examine the degree to which older citizens successfully use these opportunities. The subject matter of the paper is Internet usage by the elderly. It points to the benefits the elderly are getting from Internet usage as well as the barriers they come across. Starting from the concept of the digital divide, Internet usage by the older Serbian population is analyzed. Finally, the measures to be taken to create favorable conditions for Internet usage by elderly are pointed out.
\end{abstract}

Key words: the Elderly, the Internet, Access, Skills, Serbia.

\section{INTRODUCTION}

In the last decades, the problems of the elderly have attracted the attention of the scientific and wider public thus imposing themselves as issues of public policies. The growth of interest in the elderly is conditioned by the changes that the contemporary societies have recently been facing. The most significant changes are reflected in an increasing share of the elderly in the overall population as well as in the change of their social status. In the pre-modern societies, older people most often enjoyed great respect as carriers of tradition and experience, while care about them was taken mainly within the family. In contemporary society, their position changes in the sense that their reputation and influence are decreasing. The domination of the nuclear family and the weakening of

Received March 26, 2017 / Accepted June 19, 2017

Corresponding author: Gordana Stojić

University of Niš, Faculty of Philosophy, Cirila i Metodija 2, 18000 Niš, Serbia

E-mail: gordana.stojic@filfak.ni.ac.rs 
family solidarity have led to the fact that the elderly are no longer exclusively cared for byte family: the number of older people living alone or in special residential settings is growing. That is the reason why the need for social intervention is also growing to satisfy their specific needs such as health service, accommodation and care, material aid to the poor, environment support and the like. In Serbian society, the most important factor of the marginalization of the older population is poverty and a lack of social care about them (public services, developed private sectors of elderly-oriented services).

An increased sensibility for exploring different forms of inequality (besides property ones) as well as the development of new conceptual frames (social exclusion, marginalization, ageism) have enabled the detection of more subtle forms of discrimination and social exclusion. The generational differences are becoming significant for the identification of those groups that are deprived of the possibilities for using social resources and of a life worthy of the citizen of contemporary society.

\section{THE ELDERLY IN THE INFORMATION AGE}

Contemporary society is characterized by the expansion of information-communication technologies (ICT), most of all, the Internet. The rhythm and range of the changes have motivated some authors to speak about a new type of society in the making (postindustrial, information, networked society) (Bell 1973; Castells 2000; Van Dijk 2012). No agreement exists regarding social consequences of the Internet expansion - optimist views are opposed to pessimist ones when it comes to the influence of new technologies on social inequalities, community and social capital, politics, organization and culture (DiMaggio et al. 2001). The social changes related to the ICT expansion are permeating the whole society - from economy through social organization to everyday life, forms of communication and patterns of interaction. The Internet is a means of more efficient and faster completion of various activities, satisfaction of different needs and access to social resources. That is why it is important to examine the degree to which older citizens successfully use these opportunities.

The first Internet users were younger, better educated citizens of a higher material standing. Along with an increasing number of users, the Internet is also spreading among other categories of the population. At the same time, contents and services available through the Internet become more varied, thereby making it an important tool for carrying out various activities in everyday life. However, even in the societies characterized by a very high rate of Internet penetration, there are differences regarding access to Internet depending on age, education, gender, material status, (in some countries) race/ethnicity, (rural/urban) place of residence, invalidity, and the like. These new forms of inequality that emerge in the information society are differently named in the referential literature - for instance, as divided into the "haves" and "have-nots", the digital divide, digital gap, digital inequalities or digital exclusion (Castells 2000; Norris 2001; DiMaggio and Hargittai 2001; Hargittai 2002; Castells 2003; Van Dijk 2012). While the first research projects were directed at inequality in Internet access, attention was more and more focused upon inequalities in the needed Internet skills and usage of Internet for different purposes. "By "digital divide" we refer to inequalities in access to the Internet, extent of use knowledge of search strategies, quality of technical connections and social support, the ability to evaluate the quality of information, and diversity of uses" (DiMaggio et al. 2001, 310). 
The adoption of new technologies has taken on a different pace when it comes to the generation affiliation. Today's generation of youth are growing up in a digital environment with the Internet often being their first choice for getting information and performing different activities (Prensky 2001); the adult population has often acquired the skills and habits of using the Internet at school and in the workplace while many members of the older generation lack the experience of having come across an obligation or possibility of using the Internet in an organized context. That is why attention is directed to difficulties (barriers) in using the Internet by the elderly as well as the benefits they can gain from integrating the Internet into their everyday life and the measures that should be taken for their inclusion into the information society. In doing so, the starting point is an assumption that not only Internet usage can improve the quality of life of the elderly and reduce their social exclusion, but also that the non-usage of Internet increases their social exclusion in an environment in which everyone is online.

The subject matter of the paper is Internet usage by the elderly. It points to the benefits the elderly gain from Internet usage as well as the barriers they come across. Starting from the concept of the digital divide, Internet usage by the older Serbian population is analyzed. Finally, the measures to be taken to create favorable conditions for Internet usage by the elderly are pointed out.

\section{BENEFITS FROM THE INTERNET FOR THE ELDERLY}

To older people the Internet offers possibilities for life quality improvement and reduction of dependence on the environment (family and public services). Research studies show that older users stress, as positive aspects of the Internet usage, networking and communication with other people (friends and family members), a pleasure in learning which increases their self-confidence and self-esteem as well as practical uses from accessing information and positive experience of learning (Gatto and Tak 2008, 805-807). Unlike other activities that are time or space bound or bound by the presence of other people, Internet usage is, by nature, individual and time-flexible - namely, people can be involved in activities to their own liking, when and how much they want it in accordance with their needs and conditions (Shapira et al. 2007, 482). These features of Internet usage make it very favorable for older people.

The elderly can use the Internet for acquiring information in situations when they need it. Three wider contexts in which they need information are specific for them, namely, "at key life course transitions (e.g. retirement or moving into supported accommodation), around major life events or points of vulnerability (illness of self or close relative or friend, bereavement), and relating to "daily hassles"' (Godfrey and Johnson 2009, 635). Of special importance for the elderly is getting information about health.

The Internet enables them to sustain the existing as well as establish new social connections and relations in not only the virtual world, but also individual and group ones in real life (Petrović 2009, 38). Internet usage enables older people to communicate with kin and friends and to preserve old acquaintances. Likewise, they can establish communication with the people with similar interests and in this way overcome social isolation and loneliness. Unlike young users, older ones do not spend time on the Internet at the expense of face-to-face interaction with other people, but by reducing time-expenditure on television and radio (Gatto and Tak 2008, 802). 
Learning is one of the most important activities contributing to active aging. Older people can use the Internet for acquiring knowledge in various fields (use of electronic educational contents, online courses and the like). Moreover, the very learning of how to use computers and the Internet contributes to the psychological welfare of the elderly in many ways: "learning of an innovative field; social benefits of using online communication: experiencing involvement and action; and positive feelings stimulated by using internet" (Shapira et al. 2007, 482).

Internet usage increases the self-confidence and self-esteem of the elderly. Those among them who feel like lagging behind modern society are enabled to feel, thanks to using the Internet, that they are keeping pace with it, that they understand what people around them are talking about (Melor et al. 2008, 36).

The elderly can perform various activities online to satisfy their needs without leaving their homes, such as buying and selling, money transactions, medical consulting, usage of public administration services and the like. In this way, they can overcome the limitations arising from specific features of their life age (problems with mobility, health problems, invalidity, etc.). "Overall, then, it seems that the use of computers and the Internet can empower older people, contribute to their quality of life and help in coping with this group's typical mental and physical difficulties. Aging might then become less difficult as older people gain greater opportunities to be more independent, less socially isolated and more cheerful" (Shapira et al. 2007, 477).

\section{BARRIERS IN INTERNET USAGe By OLDER PEOPLE}

Some people at the start of their old age have already developed Internet skills and habits (for instance, people who have undergone job training and continued to keep it up in retirement) but most of the elderly have not used the Internet before; that is why we should stress the barriers they face in accessing and using the Internet. Van Dijk (2012, 197-202) distinguishes four successive kinds of digital technology access: motivation for access, physical and material access, digital skills and usage.

The encouragements for mastering Internet skills are needed because a part of the older population either does not want or cannot start using the Internet. People can have a negative attitude toward the Internet since they have either estimated they do not need it or they are unfamiliar with the possibilities it offers them. They might even try it out before giving it up altogether because they cannot easily find the contents they are interested in (Dobransky and Hargittai 2006, 317). Other barriers to Internet usage by older people can include frustrations (due to a lack of skills, slow advancement, technical problems), functional constraints (physical and mental constraints to more frequent use or for a longer period of time), distrust (fear of jeopardizing privacy or distrusting the Internet as a source of information) and time (spending of time that could be used for other activities, fear of becoming dependent and habituated, lack of time for Internet activities) (Gatto and Tak 2008, 807-808).

To use the Internet, older people must have access to appropriate devices and connections. The very possession of Internet access at home is a permanent expenditure due to subscription and this can affect Internet availability to older people of a poorer material status. The place from which one has access to the Internet is important: at home, the elderly can themselves determine when and how much time they are to spend surfing, in a 
familiar environment and privacy. For those who have no access to the Internet at home, the possibilities of access in public institutions are of importance.

To use numerous and various possibilities offered by the Internet it is necessary to develop digital skills. Digital skills can be defined as "the collection of skills needed to operate a computer and the Internet, to search and select information in them, to communicate with them, and to use them for one's one purposes, for example, by the creation of new web content" (Van Dijk 2012, 199).Research studies have shown that older people are lagging behind compared to young ones when it comes to operational and formal skills but that they are more successful regarding some content-related skills (valid browsing, selection and evaluation of information as well as the use of Internet as a means for special purposes) (Van Dijk 2012, 200). The efficiency of the adoption of digital skills is affected by educational level and environmental support.

Finally, "it is also important to look at differences in what people do online once they have gained access" (Dobransky and Hargittai 2006, 317). In addition to possessing the needed skills, the extent to which the elderly will use the Internet for various purposes also depends on the availability of the contents compatible with their age (interests, needs, physical and mental capacities).

Older people do not make up a homogeneous group, so it is important to see how other factors of the digital divide affect access and usage of the Internet. It is a greater possibility that the elderly would use the Internet if they were of a better material status and a higher level of education, if they lived in a household with children, were citydwellers, belonged to particular ethnic groups and have no invalidity.

\section{OLDER USERS OF INTERNET IN SERBIA}

This section of the paper refers to the characteristics of the Internet usage by the elderly (65 to 74 years of age) in Serbia, that is, access, skills and use.

The characteristics of Internet usage by the elderly are represented based on the research entitled The Use of Information-communication Technologies in the Republic of Serbia carried out by the Statistical Office of the Republic of Serbia (SORS) according to the EUROSTAT methodology once a year since 2006. The data used are mainly taken from the research carried out in 2015 while the previous research studies were used when certain trends were pointed out. The research study was done on the territory of Serbia (without Kosovo and Metohija) on a two-phase stratified sample of 2,355 persons out of which 706 are people of 65 to 74 years of age (SORS 2015,11). There are two reasons for choosing this age category. If a lower age limit was taken into consideration, the sample would include the still active working population whose way of life and social position are considerably different from those of people older than 65. In that case no specific traits of the oldest would come into prominence. The other reason is the way in which the data of the SORS research are represented by age categories.

The development of the Internet in Serbia was first slowed down due to the international sanctions in the 1990s and then by underdeveloped infrastructure, an economic crisis and the poor purchasing power of the population. In the last ten years, however, the number of households possessing a computer and Internet access has been growing thus reaching, in 2015, slightly less than $2 / 3$ households (Graph 1 ). 


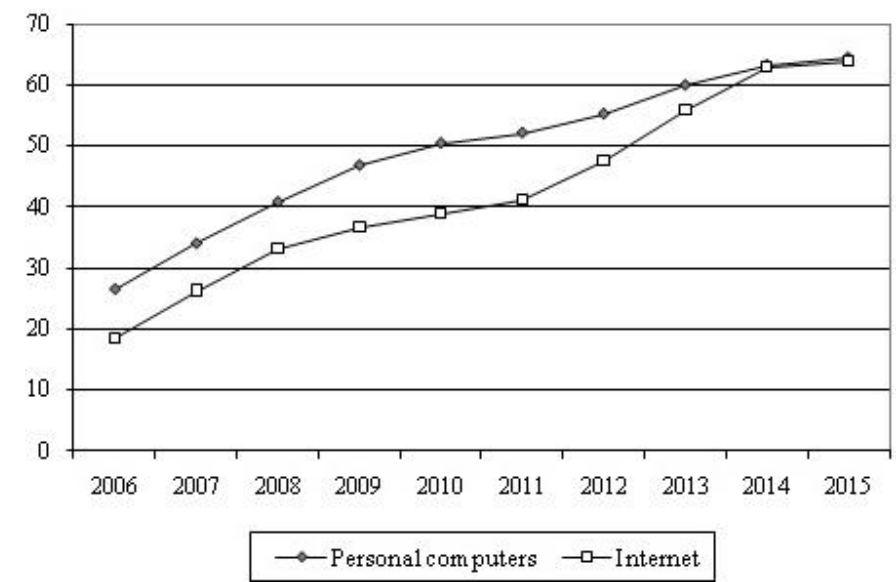

Graph 1 Possession of computers and Internet connections (Serbia 2006-2015) Source: Statistical Office of the Republic of Serbia 2015, 13, 14.

The trends in the use of IC technologies in the period from 2006 to 2015 are shown in Graph 2. The use of mobile phones was intensively increasing till 2008, thereafter it slowed down; in the year of 2015 it reached the level of $91,4 \%$ of the overall population which means it was coming close to the saturation limit. A closer look at the use of computers and Internet would reveal several facts. Firstly, the starting position is very low: in 2006 when the first research was carried out in Serbia, one third of the population used a computer $(33,6 \%)$ while less than one fourth used the Internet $(23,9 \%)$. Secondly, the difference between the shares of computer-users and those of the Internet was more than $10 \%$ in the first six years; thereafter the number of Internet users has been increasing at a quicker pace and from the year 2014 the number of people using of a computer and the Internet have virtually become equal.

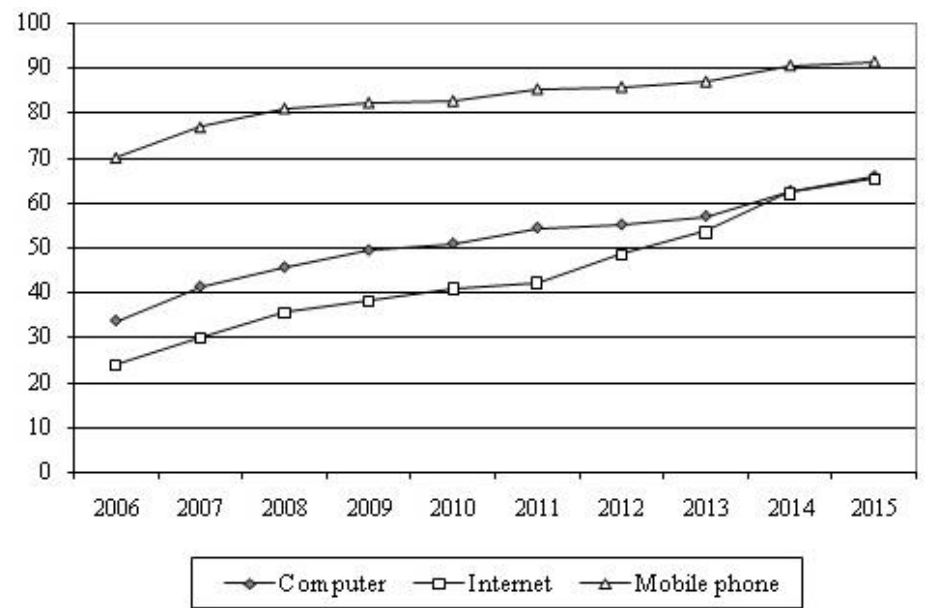

Graph 2 Use of ICT devices in Serbia 2015-2016

Source: Statistical Office of the Republic of Serbia 2006, 33, 35; 2007, 35, 37; 2008, 37, 39; 2009 , 35, 39; 2010, 39, 41; 2011, 37, 39; 2012, 37, 41; 2013, 37, 39; 2014, 35, 37; 2015, 22, 37, 39. 
How is this growth distributed among different age categories of the population? There is a direct correlation between the age group and Internet access (Graph 3). For the users up to 34 years of age the characteristic trend is a linear one, while with older categories there is a quickening of growth after 2010, especially when it comes to the users of the age from 35 to 44 . The difference between the three youngest categories (up to 44) was reduced after ten years but it has increased with respect to older categories. Though the number of older users is increasing, the Graph shows a marked divide: on the one hand, there are users up to 44 years of age while on the other there are those from 45 to 64 years of age. At the bottom of the scale are the oldest users who are lagging behind in participation compared to the closest age category by $27,9 \%$. Their growth is the slowest: in ten years the number of Internet users in this category has increased by less than $10 \%$ while the pace of growth has not quickened; on the contrary, it has slowed down.

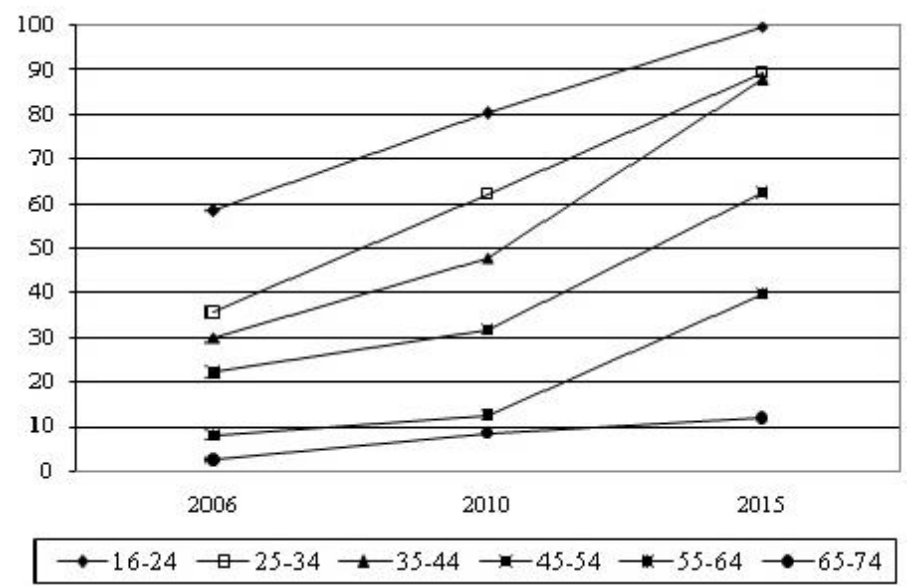

Graph 3 Use of Internet among different age categories (2006, 2010, 2015)

Source: Statistical Office of the Republic of Serbia 2006, 32, 34; 2010, 38, 40; 2015, 36, 38

Regarding both relatively (with respect to other age categories) and absolutely (as a share of the Internet users with respect to overall population of a given age group), the oldest are characterized by a low level of Internet usage and access to the Internet. In the year 2015 , only $13,2 \%$ of older people used a computer ${ }^{1}$ in the last three months while $82,2 \%$ never used it. While with the younger categories (up to 44) the number of Internet users is somewhat greater than that of computer users (since the Internet can be accessed by other devices as well) this is not the case with the elderly. Namely, in the last three months the Internet was used by $11,7 \%$ of those older than 65 to 84 , and $6 \%$ never used it. Lesser is the frequency of Internet usage with respect to the overall user population: access to the Internet is daily or almost daily available to $85.9 \%$ of the overall user population while among the oldest users this share is 75, 5\% (SORS 2015: 36-38).

The location at which a computer is used and the Internet is accessed is important since it affects the quality of usage (available time, comfortableness, habit, autonomy). As with the

\footnotetext{
${ }^{1}$ Users of computers and the Internet are those participants who state, in their responses, that they used them in the previous three months.
} 
other age categories, the elderly also mostly use a computer and Internet at home (SORS 2015: 38), followed by those who access it in someone else's house, and then at work. At first sight, this may seem very encouraging in the sense that the majority have access to it under favorable conditions. However, this means, at the same time, that all the older people who have no computer and Internet access at home (for instance, those that cannot afford buying a computer or paying subscription for the Internet due to low material status) do not use at all access to a computer and the Internet in public places (first of all, libraries, hotspots in public institutions and the like). The usage of ICT access at such locations is otherwise quite small (for instance, Internet in public libraries was used, in 2015, by only 3, $2 \%$ of internet users). We possess no data about whether such locations are unavailable (or non-existent in the community) or simply whether the users are not informed about the possibility of using these services under favorable conditions. One of the measures carried out for the sake of reducing the digital divide is the setting-up of hotspots in local centers and public institutions with the aim of making the ICT available even to those population categories that lack the possibility to efficiently use them at other places. The general view of the possibilities of Internet access of the oldest users is completed with the data that more than three-quarters $(78,1 \%)$ of them have no access to the Internet via mobile devices outside their home or job (mobile phone, portable computer and the like).

Digital skills are the pre-requisite for using a computer and accessing the Internet. Older users have acquired their skills primarily through the informal help of their friends, cousins, colleagues as well as self-learning through work and with the use of books, CDs and the like (Table 1). One fifth of them have acquired their skills at professional training courses at their employer's request; this is followed by courses in schools for adult training and formal education. As can be expected, with respect to the overall population, the greatest difference is in acquiring skills through formal education that was, for this age category, mainly unavailable. On the other hand, data show that the job requirements are a factor powerfully affecting the acquisition of information literacy - somewhat more than the third of the elderly have acquired these skills by self-learning through work while each fifth of them have undertaken professional training at their employer's request. When it comes to self-learning by means of books, discs and the like, no difference exists between the elderly and the other users: they have attended, in a somewhat greater number, courses for adult instruction.

Table 1 Ways of acquiring computer and Internet skills

\begin{tabular}{lcc}
\hline Where and how computer and Internet skills are obtained & All users & $\begin{array}{c}\text { Users aged } \\
65-74 \text { years }\end{array}$ \\
\hline Informal assistance from colleagues, relatives, friends & 68,1 & 72,8 \\
Self-study in the sense of learning-by-doing & 50,1 & 35,9 \\
Formal education (school, university) & 42,1 & 11,4 \\
Self-study using books, cd-roms, online courses, Wikipedia & 33,8 & 31,4 \\
Training courses in adult education center & 9,6 & 13,2 \\
Vocational training courses (on the demand of the employer) & 9,1 & 20,6 \\
Some other way & 1,6 & 3,9 \\
\hline
\end{tabular}

Source: Statistical Office of the Republic of Serbia 2011, 52.

When it comes to the activities done on a computer and the Internet as indicators of Internet skills, about 1/5 copied or moved files, 1/3 used Word for text processing and 
each tenth elderly citizen created a presentation. In the overall population of users, the first two operations are done by more than a half, while a third is done by more than a fourth of users. Care should be taken while interpreting these data since the responses reflect not only skills but needs as well. It can be assumed that some older people had no need for certain applications such as text editing in Word, use of software for work with tables or creation of presentations. That is why it is important to take into consideration the purposes to which they use the Internet and whether they come across difficulties in doing so. It is exactly through various purposes to which they use the Internet that motivation, information and skills are expressed - the knowledge that something can be done through the Internet, that this is a faster and more comfortable way of doing things, that the needed skills for this are possessed or that it is known how and where they can be mastered and that the person is motivated to put some effort into overcoming possible problems. This also shows the extent to which older people have integrated the Internet into their everyday life as a means of satisfying a variety of needs and not only as a "substitute for the phone and newspapers."

Various possibilities offered by the Internet can be classified into several basic groups: communication, access to information, civil and political participation, professional improvement, completion of financial services, usage of public administration services, learning.

The elderly mostly use the Internet for communication purposes: email is used by $62 \%$; almost half of them participate in social networks while slightly fewer of them use phone/video conversations (Table 2). On the contrary, only every tenth one of them puts private content on web sites and shares them with other people. Older people tend to practice more those activities that present lesser threats to their privacy and that do not require more sophisticated digital skills.

Table 2 Use of Internet for communication purposes

\begin{tabular}{lcc}
\hline Activities & All users & $\begin{array}{c}\text { Users aged } \\
65-74 \text { years }\end{array}$ \\
\hline Sending/Receiving e-mails & 66 & 62,9 \\
Telephoning/video calls over the Internet & 52,7 & 45,6 \\
Participating in social networks & 75,6 & 49,0 \\
Uploading self-created content & 38,1 & 11,9 \\
(text, photos, music, videos, software...) & & \\
\hline
\end{tabular}

Source: Statistical Office of the Republic of Serbia 2015, 40.

The elderly mostly ask for information about commodities and services while more than a half of them read newspapers and journals online and consult Wikipedia. Half of them use the Internet to get information about health. It is interesting that, regarding frequency, the sought-for information pieces are ranked in the same way when it comes to the overall population of Internet users and to older people while the differences between them range from $3,7 \%$ (seeking information about commodities and services) to $19,2 \%$ (information about education). 
Table 3 Access to information

\begin{tabular}{lcc}
\hline Activity & All users & $\begin{array}{c}\text { Users aged } \\
65-74 \text { years }\end{array}$ \\
\hline Reading on-line news/newspapers/news magazines & 62,3 & 55,2 \\
Seeking health related information & 56,8 & 49,9 \\
Looking information about education, training or course offers & 56,8 & 37,6 \\
Consulting Wikipedia (to obtain knowledge on any subject) & 61,6 & 51,3 \\
Finding information about goods or services & 67,7 & 64,0 \\
Downloading software (except for PC games) & 18,8 & 8,4 \\
\hline
\end{tabular}

Source: Statistical Office of the Republic of Serbia 2015, 40.

In the last few years more and more public administration services have become available online, while e-commerce and e-banking are rapidly developing in Serbia. A fourth of the elderly Internet users $(26,4 \%)$ are getting informed via web sites of public institutions while the share of those who have either downloaded or uploaded forms is almost twice as small $(13,7 \%$, that is $14,1 \%)$. Most them have not sent any forms due to not feeling any need for it but every tenth participant states, as a reason for not doing it, a lack of skills (SORS 2015:44). When it comes to financial transactions, every fifth older Internet user has used services referring to travel and accommodation while every tenth has used Internet banking (Table 4). The elderly rarely buy goods via the Internet (4/5 never did it) but one third sells goods via the Internet. Selling via the Internet is the only activity that the elderly are doing to an extent higher than the average for all the Internet users. Like all the other Internet users, the elderly do not buy via the Internet since they prefer direct shopping or do not trust the very purchase process (delivery, complaints and the like). They state as the reason for this, to a large extent, a lack of skills (15\%) or a lack of card for Internet payments $(28,7 \%)$.

Table 4 Use of financial services

\begin{tabular}{lcc}
\hline Activity & All users & $\begin{array}{c}\text { Users aged } \\
65-74 \text { years }\end{array}$ \\
\hline Using services relating to travel or accommodation & 30,4 & 19,5 \\
Selling of goods or services (e.g. via auctions) & 32,1 & 36,2 \\
Internet banking & 12,9 & 12,6 \\
Buying or ordering goods or services over the Internet & 22,7 & 9,2 \\
\hline
\end{tabular}

Source: Statistical Office of the Republic of Serbia 2015, 40, 46.

Other activities (learning, career and civil and political participation) are less present. As expected, a very small number of the elderly use the Internet for career-oriented activities since they mostly make a non-active population (in working terms). Information related to online learning is requested by every tenth older person while online courses are attended by $4,2 \%$ of them (Table 5). Of all the online activities, the elderly least use the Internet for civil and political participation. A decentralized structure of the Internet offers possibilities for the voice of the elderly to be heard not only when it comes to their problems but also actual political and social issues. However, the elderly in Serbia (almost) make no use of these possibilities of civil and political participation: only $3.3 \%$ of them post opinions about social issues via blogs and/or social networks and no one takes participation in on-line discussions or votes to define social issues (SORS 2015: 40). 
Table 5 Use of Internet for the purposes of learning and civil and political participation

\begin{tabular}{lrc}
\hline Activities & All users & $\begin{array}{c}\text { Users aged } \\
65-74 \text { years }\end{array}$ \\
\hline $\begin{array}{l}\text { Doing an online course (from any field) } \\
\text { Looking for information on the Internet for learning purposes }\end{array}$ & 5,3 & 4,2 \\
(audio-visual materials, e-textbooks...) & 22,7 & 9,5 \\
Chatting or discussing on on-line forum & 8,8 & 0,5 \\
Other & 72,8 & 89,0 \\
\hline
\end{tabular}

Source: Statistical Office of the Republic of Serbia 2015: 40

It is interesting that, comparing to other age groups, the elderly are least concerned about safety due to possible problems of using the Internet for private purposes (SORS 2015, 56).

To complete the picture about the Internet usage by the elderly it is important to point to other factors that, in combination with age, affect access to and use of the Internet. The most prominent differences regarding access to the Internet in Serbia are expressed with respect to the material status of a household. In so doing, the households with 300 Euros of income $(46,4 \%)$ are clearly separated from those having 300 to 600 and over 600 Euros $(80,3 \%, 87$, and $7 \%$ ) (SORS 2015:15). Also, there is a prominent gap between the rural and urban population $(53,2 \%: 70,1 \%$ when it comes to households with the Internet). When it comes to Internet usage, after the age group, the most prominent is polarization with respect to educational level: $38,2 \%$ of citizens with less than secondary school use the Internet, unlike $78,2 \%$ of those who have completed secondary school and $87,8 \%$ of those with high and higher education.

\section{CONCLUDING REMARKS}

The participation of the elderly in the possibilities offered by the development of information society is important not only for them but for society as a whole. This contributes to the welfare of individuals as well as to the reduction of costs and a more efficient work of public services. Moreover, along with the expansion of the informationcommunication technologies, access to particular resources and services can be made difficult for those older people who do not want or cannot use the Internet. That is why the strategies of development of information society as well as care about the elderly and active aging comprise measures that can stimulate the elderly besides creating a favorable social environment for Internet usage. These measures should take into consideration the characteristics of older Internet users and their real and perceived barriers and benefits from Internet usage. The measures that meet the needs of the older population include training for work on a computer and Internet access, development of educational materials available via the Internet, online social support and computer-mediated communication (Gatto and Tak 2008, 803, 810) as well as development of elderly-friendly interface and software and a favorable physical environment (Shapira et al. 2007, 483). The support of the environment is very important for encouraging the elderly to learn and use the Internet. In that sense, the support of family members and friends has special importance as a factor motivating older people to start learning and using the Internet (Gatto and Tak 2008, 804).

The older population do not make up a homogeneous group; they differ among themselves regarding their material status, education, gender, type of settlement they live 
in (urban, rural), health state, invalidity. They also differ regarding their previous professional experience, physical and mental abilities and age group. Moreover, they differ as to whether they live alone, with families or in residential care settings. The measures directed to the increase of Internet usage should consider these differences because different types of older adults are likely to have different types of digital (dis)engagement (Deursen and Helsper 2015).

When it comes to Serbia, the most important problem is access. The measures to be taken refer to motivation and access provision. The campaigns directed at the reduction of a negative attitude of the elderly to the Internet should stress the concrete benefits they may have from it and this in a way appropriate for them, just as they should encourage the environment to give them support. Another group of measures refers to the provision of a physical access and instruction to the elderly, namely, one that needs united efforts of public services, local communities and civil society. It is important to enlarge the possibilities of Internet access in public places such as libraries as well as to create new ones (in local communities, associations of pensioners and the like). Special attention should be given to the elderly with invalidity, low income and rural dwellers. As for contents, it is necessary to create web sites adjusted to the mental and physical abilities of older people, namely, those that would, in one place, bring together information that is of interest for the elderly and local contents. Furthermore, stimuli for the elderly to use the possibilities of online learning and participate in social networks and various forms of social activism are especially important. As most of the elderly in Serbia are non-users, "traditional" forms of access to public services should still be enabled for them.

To understand specific traits of the attitude of the elderly toward the Internet as well as building up efficient stimulation measures, it is necessary to carry out research studies that take into consideration both those who use it and those who do not use it as well as the ways in which attitudes and behavior change in time. Finally, efficient measures are not possible without the active participation of older people in their preparation and application.

Acknowledgement: The paper is a part of the research done within the project Tradition, Modernization and National Identity in Serbia and the Balkans in the European Integration Process (179074), financed by the Ministry of Science and Technological Development of the Republic of Serbia and implemented by the Centre for Sociological Research at the Faculty of Philosophy, University of Niš.

\section{REFERENCES}

Bell, Daniel. The Coming of Postindustrial Society. New York: Basic Books, 1973.

Castells, Manuel. Informacijsko doba: ekonomija, društvo i kultura. Sv. I. Uspon umreženog društva. Zagreb: Golden marketing, 2000.

Castells, Manuel. Internet galaksija. Razmišljanja o Internetu, poslovanju i društvu. Zagreb: Naklada Jesenski i Turk, 2003.

DiMaggio, Paul, and Eszter Hargittai. 'From the 'Digital Divide' to 'Digital Inequalities': Studying Internet Use as Penetration Increases", Princeton University, Center for Arts and Cultural Policy Studies, Working Paper 15, 2001. Available at: http://www.princeton.edu/ artspol/workpap/WP15\%20-\%20DiMaggio+Hargittai.pdf (accessed January 17, 2016).

DiMaggio, Paul, Eszter Hargittai, Neumann, W. Russell, and John, P. Robinson. "Social Implications of the Internet". Annual Review of Sociology 27 (2001): 307-336.

Dobransky, Kerry, and Eszter Hargittai. "The Disability Divide in Internet Access and Use". Information, Communication and Society 9 (2006): 313-334. 
Gatto, Susan L., and Sunghee H. Tak. "Computer, Internet, and E-mail Use among Older Adults: Benefits and Barriers". Educational Gerontology 34 (2008): 800-811.

Godfrey, Mary, and Owen Johnson. "Digital Circles of Support: Meeting the Information Needs of Older People". Computers in Human Behavior 25 (2009): 633-642.

Hargittai, Eszter. "Second-level Digital Divide: Differences in People’s Online Skills". First Monday 7 (2002). Available at: http://firstmonday.org/ojs/index.php/fm/article/view/942/864 (accessed January 15, 2016).

Mellor, David, Lucy Firth, and Kathleen Moore. "Can the Internet Improve the Well-being of the Elderly?" Aging International 32 (2008): 25-42.

Norris, Pippa. Digital Divide: Civic Engagement, Information Poverty and the Internet Worldwide. Cambridge: Cambridge University Press, 2001.

Shapira, Na'ama, Azy Barak, and Iddo Gal. "Promoting Older Adults`Well-being through Internet Training and Use". Aging \& Mental Health 1, 5 (2007): 477-484.

Statistical Office of the Republic of Serbia (SORS). The Use of Information-communication Technologies in the Republic of Serbia (in Serbian). Belgrade: Statistical Office of the Republic of Serbia, 2006, 2007, 2008, 2009, 2010, 2011, 2012, 2013, 2014, 2015. Available at: http://www.stat.gov.rs/WebSite/Public/PageView. aspx?pKey=431\&URL=http://pod2.stat.gov.rs/ElektronskaBiblioteka2/Pretraga.aspx?pubType=8\%26areaId=27 (accessed December 20, 2016).

Petrović, Dalibor. „Internet u funkciji personalnog umrežavanja“. Sociologija LI (2009): 23-44.

Prensky, Mark. „Digital Natives, Digital Immigrants”, Part I. On the Horizon 9 (2001): 1-6.

Van Dijk, Jan. The Network Society, $3^{\text {rd }}$ edition. London: Sage Publications, 2012.

Van Deursen, Alexander and Ellen Helsper. "A Nuanced Understanding of Internet Use and Non-use among the Elderly”. European Journal of Communication 30 (2015): 171-187.

\section{STARIJI KORISNICI INTERNETA U SRBIJI}

Poslednjih decenija problemi starijih privlače pažnju nauke i javnosti i postaju predmet javnih politika. Rast interesovanja za starije uslovljen je: rastom udela starijih u ukupnom stanovništvu, promenom njihovog društvenog statusa i razvijanjem novih pojmovnih okvira (društvena isključenost, marginalizacija, ejdžizam). Stariji žive danas u svetu koji širenje informaciono-komunikacionih tehnologija (IKT). Internet je sredstvo za efikasnije i brže obavljanje različitih aktivnosti, zadovoljanje različitih potreba i pristup društvenim resursima. S druge strane, usvajanje novih tehnologija odvija se različito $s$ obzirom na generacijsku pripadnost. Zbog toga je važno istraživati u kojoj meri stariji građani uspešno koriste ove mogućnosti. Predmet rada jeste upotreba interneta od strane starijih. U radu će biti prikazane koristi koje stariji imaju od upotrebe interneta i prepreke sa kojima se suočavaju. Polazeći od koncepta digitalne podele biće analiziranaupotreba interenta od strane starijih u Srbiji. Na kraju se ukazuje na mere koje se sprovode za stvaranje povoljnih uslova za korišćenje interneta od strane starijih.

Ključne reči: stariji, internet, pristup, veštine, Srbija. 